\author{
Ф. Г. Хисамитдинова \\ Институт истории, языка и литературы УФИЦ РАН \\ Уфа, Россия \\ hisamitdinova@list.ru
}

\title{
Отражение контактов с тюркскими народами в русской мифологической лексике*
}

Тюрко-русские контакты имеют давнюю историю, об этом имеется большая литература. Вместе с тем следует отметить, что не все вопросы тюрко-русских языковых контактов освещены в достаточной мере. К числу таковых следует отнести вопросы взаимодействия тюрков и русских в области мифологии. Если не считать этимологических разысканий Н. А. Баскакова по русским мифонимам Боян / Баян, Велес и Мокошь, а также включения нескольких тюркских лексем в мифологические словари русского языка, то этот вопрос фактически остается одним из самых малоизученных как в славистике, так и в тюркологии.

Между тем в мифологической лексике русских Урало-Поволжья и Сибири тюркский пласт занимает солидное место. Пер в у ю г р уп п у тюркизмов в говорах этого региона образуют мифонимы, заимствованные из мифологической лексики того или иного тюркского языка и полностью совпадающие с этимонами, ср. широко распространенные лексемы типа аба, бабай, бакши, сата, шайтан и др.

Aба. Этот мифоним-тюркизм в значении 'медведь' зафиксирован в прииртышских русских говорах. По мнению А. Е. Аникина, является заимствованием из диалектов хакасского языка [Аникин, 2000, 71-72]. Как табуированное название медведя зафиксирован в ряде сибирских, тюркских и башкирском языке в форме апа [Хисамитдинова, 2011, 29]. Первичным значением лексемы аба / ana в тюркских языках является значение 'старший родственник или родственница'; интересно отметить, что оно зафиксировано также в ряде русских говоров Урала и Сибири [СРГБ, 19; Аникин, 2000, 73].

\footnotetext{
* Работа выполнена по программе фундаментальных исследований Президиума «Этнокультурное взаимодействие народов Поволжья (по материалам традиционно-бытовой и духовной лексики)».

(C) Хисамитдинова Ф. Г., 2019
} 
Бабай. В русских говорах Урала, Приобья лексема зафиксирована в значении 'фантастическое существо, страшный старик, которым пугают детей’ [СРГБ, 21; Аникин, 2000, 104-105]. В русских старожильческих говорах средней части реки Оби, а также в украинских диалектах отмечено также значение 'домовой'. Слово широко распространено на территориях проживания русского населения. Русский мифоним бабай полностью совпадает по значению с мифонимом языка-реципиента. В частности, в башкирском языке у слова бабай также имеются значения 'домовой' и 'бука, которым пугают детей' [Хисамитдинова, 2011, 45-46].

Бакша, бакши, бакса. Лексема зафиксирована в томских говорах русского языка в значении 'колдун', 'религиозный деятель'. В астраханских русских говорах отмечены формы бакша, бакса 'шаман'. В. И. Даль также приводит этот термин как обозначение шамана. Как он пишет, бакша, бакса, баксы - «киргизский (казахский. - Ф. Х.) шаман, фигляр и гадатель, колдун и лекарь» [Даль, 1, 40]. Лексема бакши, баксы зафиксирована в большинстве тюркских языков в значениях 'учитель, наставник', ‘шаман', ‘ворожея', ‘знахарь’ и т. п. [ЭСТЯ, 2].

Cama. Лексема в значении 'камень - осколок метеорита, обладающий магическими свойствами’ зафиксирована в ряде русских говоров Сибири. В колымских и нижнеиндигирских говорах русского языка лексема сата записана в значении 'магический камень для вызывания нужной погоды' [Аникин, 2000, 488]. Безусловно, тюркизм сата в этих русских говорах восходит к якут. сата 'камень, находимый в желудках, печени крупных животных и глухаря, который способен вызвать ветер, холод, непогоду, а зимой тепло' [ДСЯС, $237]^{1}$. Интересно, отметить, что представления о магическом камне, способном изменить погоду, встречаются у многих тюркоязычных народов. Так, например, названия йәйташ (букв. «летний камень»), ямдырташ (букв. «дождевой камень»), колонташ (букв. «каменьжеребенок»), язаташ (букв. «погодный камень») 'магический камень, способный вызвать дождь и остановить его’ фигурируют у башкир [Хисамитдинова, 2011, 128, 186, 376]. Под названием ядаташ магический камень отмечается у алтайцев, телеутов, лебединцев, а также в памятниках древнетюркской письменности [Кашгари, 1; СИГТЯ,

${ }^{1}$ О рус. диал. сата, якут. cata см. также тезисы А. Е. Аникина в наст. изд. - Прим. ред. 
611-613]. Очевидно, магический погодный камень в русскую мифологию проник от тюрков.

Шайтан. Лексема зафиксирована во многих русских говорах Урала и Сибири в следующих значениях: 'черт, представитель нечистой силы', ‘бранное слово’ [СРГБ, 394], 'амбарчик с добром, охраняемый идолом', ‘идол', ‘тотем у народов Сибири', ‘сильный ветер’ [Аникин, 2000, 685], ‘черт, дьявол, бес, сатана' [Даль, 4, 618]. Это слово заимствовано из тюркских языков, где широко распространено (отмечено почти во всех тюркских языках [Радлов, 4, 928, 996; Ахметьянов, 2, 476, Аникин, 2000, 685]). Тюркский мифоним шайтан в значении 'черт, дьявол, бес, сатана' восходит к арабскому языку и считается родственным библейскому термину сатана (о мифологии шайтана см. [MHМ, 2, 636]).

В торую группу русских мифологических заимствований составляют лексемы-кальки. В качестве примера можно привести астроним Кол-звезда, зафиксированный в томских, семипалатинских, терских русских говорах в значении 'Полярная звезда' [СРНГ, 14, 133]. В русских говорах Урала для названия Полярной звезды имеется мифоним Конь на приколе [Даль, 3, 416]. Оба мифонима, безусловно, возникли под влиянием тюркских языков. Ср. названия Полярной звезды у башкир: Алтын казыл йондозо (букв. «Звезда золотой кол»), Тимер каз̧ык йондозо (букв. «Звезда железный кол»), Каз̧ык йондоз (букв. «Звезда-кол») и др. Данный мотив присутствует в якутском и других сибирских тюркских языках, а также в мифологии. В русских говорах Сибири зафиксировано еще калькированное название Большой Медведицы Лабаз-звезда, ср. якут. Арангас Сулус (букв. «Лабаз-звезда») для Большой Медведицы.

По-видимому, калькированным является название погодного камня - дождевой камень у русского населения Белорецкого района Башкортостана (С. М. Ильгамов, устное сообщение).

Третью группу тюркизмов в мифологии русских Урала и Сибири составляют тюркские, точнее восточные, мотивы. В качестве примера можно привести зафиксированное в русских говорах название мифической птицы Мага-птица / Нагай-птица, связанное, по мнению А. Е. Аникина, с тюркской собакой-птицей Симург [Аникин, 2000, 363]. Тюркские мифологические мотивы, по-видимому, присутствуют и в астрониме Мамаева дорога, отмеченном в томских говорах русского 
языка в значении 'Млечный путь' [СРНГ, 17, 349]. Мотив дороги нашел отражение также в тамбовских и тульских русских говорах в названии Батыева дорога для Млечного пути [Даль, 1, 54]. Аналогичные мифонимы зафиксированы в ряде тюркских языков и диалектов, ср. башк. Кош юль (букв. «Дорога птиц»), Каз юль (букв. «Дорога гусей»), Мамай юль (букв. «Путь / дорога Мамая»). Кстати, факт Мамай юльь отмечен и в языке сибирских татар.

Подводя итог, можно сказать, что в мифологической лексике русских говоров Урало-Поволжья и Сибири тюркизмы занимают солидное место.

Аникин А. Е. Этимологический словарь русских диалектов Сибири: заимствования из уральских, алтайских и палеоазиатских языков. М. ; Новосибирск, 2000. Ахметьянов Р. Г. Этимологический словарь татарского языка : в 2 т. Казань, 2015.

Даль В. И. Толковый словарь живого великорусского языка : в 4 т. М., 1994.

ДСЯС - Диалектологический словарь языка саха / отв. ред. Е. И. Коркина, М. С. Воронкин. Новосибирск, 1995.

Махмуд ал-Камгари. Диван лугат ат-турк (Свод тюркских слов) : в 3 т. / пер. с араб. А. Р. Рустамова ; под ред. И. В. Кормушина. М., 2010.

МНМ - Мифы народов мира : энцикл. : в 2 т. / под ред. С. А. Токарева. М., 1997.

Радлов В. В. Опыт словаря тюркских наречий : в 4 т. (8 кн.). СПб., 1893-1911.

СИГТЯ - Сравнительно-историческая грамматика тюркских языков. Пратюркский язык-основа. Картина мира пратюркского этноса по данным языка / отв. ред. Э. Р. Тенишев, А. В. Дыбо. М., 2006.

СРГБ - Словарь русских говоров Башкирии : А-Я / отв. ред. З. П. Здобнова. Уфа, 2008.

СРНГ - Словарь русских народных говоров / гл. ред. Ф. П. Филин (вып. 1-22) ; Ф. П. Сороколетов (вып. 23-42) ; С. А. Мызников (вып. 43-). М. ; Л. ; СПб., 1965-. Вып. 1-.

Хисамитдинова Ф. Г. Словарь башкирской мифологии. Уфа, 2011.

ЭСТЯ - Этимологический словарь тюркских языков / сост. Э. В. Севортян и др. М. ; Астана, 1974-. Т. 1-. 